\title{
Brighton Clark "Bugs" Cain (1897 - 1951): A Man Who Inspired Children to Love Insects ${ }^{1}$
}

\author{
Lawrence J. Hribar ${ }^{2}$
}

\begin{abstract}
Brighton Clark "Bugs" Cain was a naturalist who was professionally active in California (USA) during the 1920s to 1940s. Through the Boy Scouts of America, Cain helped popularize entomology with children, some of whom became famed entomologists.
\end{abstract}

Key Words: Brighton Clark Cain, entomology, children

Many people can trace the beginning of their interest in their life's work to the influence of one particular individual. Quite often this influence comes in childhood or early youth. One such individual who inspired a generation of young boys in California was "Bugs" Cain. Brighton Clark Cain was born in Salt Lake City, Utah on May 8, 1897, the son of 30-year-old parents Addison Cain and Frances Lawrence Cain, both of whom were born in Iowa. His father worked in real estate. He was born at the family home at 333 Water Street and his birth was attended by Dr. I. J. Douglas (Salt Lake County Birth Records, undated).

The Stanford Daily newspaper reported that Bugs Cain received his Bachelor of Arts degree in Entomology from Stanford University in 1923 and his Master of Arts degree in Entomology also from Stanford University in 1924. He wrote his thesis on the biology of earwigs (Cain 1924). Cain is listed in the Dictionary of Entomology (Gordh 2001) and in the Stanford University Alumni Directory (Anonymous 1921). As far as I know, Cain lived in California most of the rest of his life.

Bugs Cain was a professional Scouter, employed as a naturalist by the former Oakland Area Council Boy Scouts of America, now part of the San Francisco Bay Area Council. Numerous brief notices in the newspaper Oakland Tribune report Cain giving talks to groups or presenting merit badges to Boy Scouts. He was also mentioned in an article in the Elyria (Ohio) Chronicle Telegram, again mentioning his work with Boy Scouts. Bryant (1931) mentions Cain's activities with Boy Scouts in a report to the State Government. Cain retired from professional Scouting on September 1, 1950.

Cain was responsible for influencing no less than five prominent entomologists in their youth: four coleopterists, cousins J. Linsley Gressitt (also a medical entomologist), E. Gorton Linsley, John F. Lawrence; and the hemipterist Robert L. Usinger, and E. C. Zimmerman (Ivie 2005). Radovsky (1980) also

\footnotetext{
${ }^{1}$ Received on July 8, 2019. Accepted don July 16, 2019. Last revisions received on July 22, 2019.

${ }^{2}$ Director of Research, Florida Keys Mosquito Control District, 18 Aquamarine Dr, Key West, Florida 33040 USA. E-mail: 1hribar@keysmosquito.org
}

DOI: 109784/LEB7(1)Hribar.01

Electronically available on October 16, 2019. Mailed on October 16, 2019. 
credits Cain for inspiring the aforementioned five and includes a sixth individual, W. Harry Lange, a lepidopterist and a student of agricultural pests' control. Linsley (1969) recounts that, when he and Usinger were Boy Scouts, Cain introduced them to several professional and amateur entomologists whose acquaintance was invaluable to the two young men in their development as scientists. Usinger himself credited Cain for encouraging his interest in insects (Usinger 1972). Later in Cain's life, six professional entomologists hosted an anniversary dinner in Cain's honor and presented him with a book consisting of their collected and bound scientific papers; the entomologists are not named (Usinger 1952). A retired medical doctor described the influence that Bugs Cain had on him as a youth (Mill Valley Public Library 2016, Griffin undated). Photographs of Cain in action can be viewed on Griffin's web page, http://martingriffin.org/about/the-boy-scouts/

Cain is mentioned numerous times in The Gull, the magazine of the Audubon Society of the Pacific. He is listed as holding several offices, giving talks to groups, making presentations to the Association, leading field trips, and reporting bird sightings. He was a member of the Pacific Coast Entomological Society from 1923 until his death (Usinger 1952). One of Cain's anecdotes about a rattlesnake apparently detecting his presence from quite a distance away is repeated by Klauber (1972, volume 1). Cain published an article in the Journal of Economic Entomology, "Interesting Boy Scouts in entomology", in 1927 (Cain 1927). This was not a scientific paper, but the text of a talk he had given during the Twelfth Annual Meeting of the Pacific Slope Branch, American Association of Economic Entomologists.

Cain died in Palo Alto, California on May 19, 1951. A brief obituary of Cain was written by Usinger (1952) and published in Pan-Pacific Entomologist. The Hayward, California, newspaper, The Daily Review issue for May 21, 1951, reports that Bugs Cain took his own life on May 19th of that year. The article further states that he had left a note for his wife mentioning illness as the reason for his actions.

After Cain's death, a Bugs Cain Memorial Fund was established to provide money to construct a nature center in Lakeside Park in Oakland, California (Usinger 1952). His collection and library were given to the Oakland Park Department by his widow (Cotter 2016). According to Oaklandwiki (undated), a portrait of Bugs Cain hangs in the center's library; the article implies that his books and drawings may no longer be there.

The impact Bugs Cain had on the science of entomology may be best illustrated by the following quote, popular among adult Scouters: "A hundred years from now it will not matter what my bank account was, the sort of house I lived in, or the kind of car I drove. But the world may be different, because I was important in the life of a boy (Witcraft 1950)." 
Acknowledgments

Several reviewers offered suggestions that helped improve this paper.

\section{Literature Cited}

Anonymous. 1921. Stanford University Alumni Directory and Ten Year Book (Graduates and NonGraduates). III. 1891-1920. Stanford University, California, USA. 696 pp.

Bryant, H. C. 1931. Report of Bureau of Education and Research. State of California Department of Natural Resources, Division of Fish and Game. Thirty-first Biennial Report for the years 19281930. Appendix to the Journals of the Senate and Assembly of the 49th Session of the Legislature of the State of California. 5:76-89.

Cain, B. C. 1924. A study of the life history and habits of certain earwigs. M.A. Thesis. Stanford University. Palo Alto, California, USA. 54 pp.

Cain, B. C. 1927. Interesting Boy Scouts in entomology. Journal of Economic Entomology 20:679681. https://doi.org/10.1093/jee/20.5.679

Cotter, A. 2016. Bugs Cain — The Nature Man. How the Rotary Nature Center Came to Be. https://communityforlakemerritt.org/category/newsletter/ . Accessed 8 March 2019.

Gordh, G. 2001. A Dictionary of Entomology. CAB International. Oxfordshire, England, UK.1,031 pp. https://books.google.com/books?id=d0XSwMJLDg4C\&printsec=frontcover\&source=gbs_Vie $\mathrm{WAPI} \# \mathrm{v}=$ onepage $\& \mathrm{q} \& \mathrm{f}=$ false

Griffin, L. M. Undated. The story of Bugs Cain. Friends often ask Marty, Why are you obsessed with saving so much open space, rivers, and coast in California? http://martingriffin.org/about/theboy-scouts/. Accessed 8 March 2019.

Ivie, M. A. 2005. President's Corner. Entomological Society of America Newsletter. February 2005. p. 2.

Klauber, L. M. 1972. Rattlesnakes: Their Habits, Life Histories, and Influence on Mankind. Second Edition. Published for the Zoölogical Society of San Diego by the University of California Press. Berkeley, California, USA. In two volumes. Volume 1, pp. 1-740; Volume 2, pp. 741-1533.

Linsley, E. G. 1969. Robert Leslie Usinger 1912 - 1968. Pan-Pacific Entomologist 45:167-184. https://doi.org/10.1093/aesa/62.5.1218

Mill Valley Public Library. 2016. Oral History of Martin Griffin. https://millvalley.pastperfectonline.com/archive/90D3F434-095D-4151-BD74835561659480 . Accessed 8 March 2019.

Radovsky, F. J. 1980. Choosing a career: the fascination of entomology. Proceedings of the Hawaiian Entomological Society 23:263-267.

Oaklandwiki. Undated. BC Bugs Cain. https://localwiki.org/oakland/BC_Bugs_Cain. Accessed 8 March 2019.

Salt Lake County Birth Records. Salt Lake County Digital Archives. Undated. https://slco.org/archives/vitalrecords/showBirthRecords.aspx?folder $=004121037 \&$ filename $=00$ 4121037_00377\&isLedger=Y . Accessed 8 March 2019.

Usinger, R. L. 1952. Brighton Clark Cain. Pan-Pacific Entomologist 28:125.

Usinger, R. L. 1972. Robert Leslie Usinger: Autobiography of an Entomologist. Memoirs of the Pacific Coast Entomological Society 4:1-330.

Witcraft, F. 1950. Within my power. Scouting Magazine 38(8) [October]: 2. 